\title{
Effectiveness of international fund in the implementation of child rights: CSO perspective
}

\author{
Ningrum Natasya Sirait ${ }^{*}$ and Rosmalinda \\ Doctoral Program in Law, Graduate School, Universitas Sumatera Utara, Medan, Indonesia
}

\begin{abstract}
The fulfilment of child rights in Indonesia has been implemented by various parties including Community Social Organization (CSO). This study discusses the effectiveness of international fund in the implementation of child's rights. Article 4 of the Convention on the Rights of the Child (CRC) stated that state party will fulfil the rights of the child through international cooperation. CSOs with headquarters located in Medan, who manage the international funds in conducting children programs are acting as informants to this research. Depth interviews and Focus Group discussions were used as tools to obtain relevant information. The study figured out that CSOs had cooperation in implementation the child rights in Sumatera Utara Province. They cooperated with international agencies namely IOM, ACT-Japan and Catholic Relief Service. CSOs also manage to access international funds through (a) call for proposals and (b) establishing intensive communications with donor agencies. As conclusion, the use of international fund is proven to be effective based on (1) able to implement CSOs vision and mission, (2) CSOs are able to achieve program output, for example: palm oil company raise it awareness on child right and the impact to the children to access their education right especially in palm plantation area which is usually located in remote and isolated area.
\end{abstract}

\section{Introduction}

The study discussed on the efforts made by the Community Social Organization (CSO) in accessing international funds to implement child rights. In specific, the area of study is focused in the province of Sumatera Utara, Indonesia. Furthermore, the discussion will draw the effectiveness of the use of international funds to fulfil the child rights. The concept of child rights in this study is referred to Convention of the Child Rights (CRC).

There are 4 categories of child rights as stated in CRC namely; the right to survival which includes the right to preserve and sustain life and the right to the highest standard of health and the best possible care. Protection Rights, it is covering protection from discrimination, exploitation, violence and neglect. Right to development which included right to education and right to attain a standard of living by physical, mental, spiritual, moral and social development. Right of participation is the right to express opinion in all matters affecting the child. [1]

* Correspondent Author: ningrum.sirait@gmail.com 
Article 4 CRC states that the exercise of the rights of the child as mentioned in CRC shall be undertaken by the States parties and known as the state's obligations. CRC, as well as other human rights instruments such as International Covenant on Civil and Political Rights (ICCPR) and International Covenant on Economic, Social and Cultural Rights (ICECSR) mentioned four obligation of state parties namely to respect, to promote, to fulfil and to protect.[2] Mohammad Farid mention this obligation as a generic obligation, that is the obligation of State parties who ratified CRC must ensure the right to human beings in its jurisdiction without discrimination in any form.[2] This obligation is done in order to meet the standards of CRC.

The CRC is an international legal instrument approved by the UN General Assembly on November 20, 1989 in New York. CRC aims to achieve the best interest of children as the principles of international standards in concern of the children. Indonesia is a State party to the CRC based on ratification through Presidential Decree (Keputusan Presiden) namely Keppres No 36 year 1990. Article 4 CRC mentioned that, in the context of the fulfilment of economic, social and cultural rights, States Parties shall take appropriate legislative, administrative and other measures from their available sources and, where appropriate, within the framework of international cooperation. [2]

The principles of international cooperation as stated in article 4 of CRC referred to articles 55 and 56 of the United Nations (UN) Charter which mentioned that All members pledge themselves to take join and separate action in co-operation with the organizations for the achievement of conditions of stability and well-being which are necessary for peaceful and friendly relation among nations based on respect for principle of equal rights and self-determinations of people.[3] This international cooperation can be done through the elaboration of agreement, projects or programs taking a variety of forms, including technical assistance from UN agencies, bodies and organs, bilateral and multilateral aid treaties of aid and loans. [3]. Meanwhile, in Indonesia the international cooperation as mentioned in article 4 CRC regulated in Law No 37 year 1999 concerning Foreign Affair and Law No 24 year 2000 concerning International Agreement. Both laws are the basis rules for international cooperation which involved foreign governments, international organizations, UN agencies and International Non-Government Organization (I-NGO).

I-NGO has a status as an inner consultative status Committee on Non-Governmental Organizations at Economic and Social Council (ECOSOC) and United Nations Educational, Scientific and Cultural Organization (UNESCO).[4] There were 109 registered I-NGO through Forum Registration Meeting (Forum Rapat Registrasi) facilitated by Directorate of Social and Culture and International Organization of Developing Countries, Directorate General Multilateral Ministry of Foreign Affairs (Direktorat Sosial Budaya dan Organisasi Internasional Negara Berkembang, Direktorat Jenderal Multilateral Kementerian Luar Negeri) in the middle of 2011. Some I-NGOs which concern on child rights are Care International, Catholic Relief Service (CRS), Child Fund Indonesia (CFI). Inter church Organization for Development Cooperation (ICCO), Lutheran World Relief (LWR), Oxfam GB, Save the Children (SC), Terre des Hommes, the Asia Foundation and World Vision (WV).[4]

A cooperation undertaken by the Indonesian government in order to meet with the standard of CRC is the use of the Child Protection System (SPA). This project is implemented by the Ministry of Women Empowerment and Child Protection and is supported by United Nations Children's Fund (UNICEF). CSO as an organization which is working directly with the community also conducts foreign relations as stated in the article 1 of law No 37 year 1999 concerning Foreign Affair, Therefore, the government is not the only institution cooperating with the UN agency in the fulfilment of children's rights.

There was a movement of UN to decrease poverty number internationally. It was the Millennium Development Goals (MDGs) which conducted in 1990 to 2015. . It targeted 
eight key issues namely poverty, education, gender equality, infant mortality, maternal health, disease, the environment, and global humanitarian cooperation. One strategy to achieve the MDGs is with international cooperation as international fund .[5] Post 2015, UN continues the development movement known as Sustainable Development Goals (SDGs), this movement was supported by 193 states.[6] As Indonesia is a member of UN, it committed to the development issues including poverty.

Poverty is a major factor of violation of children's rights.[6] Goal No 17 of SDGs mentioned about partnerships to achieve goals, strengthen implementation and revitalize global partnerships for sustainable development.[6] This global partnership involves governments, donor agencies such as UN agencies and I-NGO for sustainable development and not limited to information sharing but also financial support. International donor agencies serve as distributors of developed country funds to developing countries as a form of their humanitarian responsibility. [5]

International cooperation, especially related to funding has always been a serious issue, especially in developing countries with bureaucratic issues. [5] Several issues of international fund management can be found in several literatures discussing international fund management in post-tsunami Aceh and earthquake. Joe Leitman, the World Bank's international fund manager for example stated that the ineffectiveness of international fund management is seen when only one per eight of the funds are absorbed from the total US\$ 12.8 billion.[7, 8] The second issue relates to the ineffectiveness in fund management related to the concept of the program. Some program implementations do not consider to local wisdom such as the issue of children, schools and orphanages, as an impact the projects do not fitted with the needs of local residents. $[8,9]$.

The effectiveness issue in managing the international funds should not induce the number and amount of the international fund. It must be existed. The international aids are needed by some developing countries. [5] Donors should consider expanding relationships with non-governmental organizations or CSOs that will mediate the distribution of aid to proper targets. This strategy will reduce the cost of bureaucracy and the risks. The Information Technology (IT) revolution must also be proclaimed in every process of assistance. The monitoring and evaluation process becomes easier and the risk of abuse can be suppressed. In addition, donors should be more selective towards programs that are a form of aid implementation. If necessary from the donor party, firstly design program criteria as detailed as possible. So the cost prediction can be compiled early. [5]

CSO is also well known as Non Government Organization (NGO). This institution is a collection of more than one person formed to achieve certain goals; most CSOs are formed by people who work voluntarily to achieve a good goal that is for the welfare of society. [10] The existence of this CSO exists at local, national, regional and even international level. They work on special issues within a particular area. [11]

There is a regulation concerning CSOs namely Law No 17 year 2013 concerning Community Organization. This rule also regulates CSOs working for the fulfilment of children's rights under CRC. Further their existence is set within Government regulation (Peraturan Pemerintah) No 58 year 2016 concerning Implementation of Law No 17 year 2013 concerning community organization. A CSO which concerned on children issues are available in Sumatera Utara Province since 1987, almost three years before the CRC was ratified by the Indonesian government. Meanwhile, two others were established several years after CRC has been ratified by Indonesia. The operational systems of these CSOs are the factors to know the ability of CSOs in managing international funds in order to fulfil child rights in accordance with the CRC.

\section{Research question(s)}


This research is intended to examine the main problem of the effectiveness of international funding managed by CSOs in the implementation of child rights in Sumatera Utara province.

This issue was developed into three research questions related to the implementation of child rights which referred to CRC such as: what programs are performed by CSOs in Sumatera Utara province for children; how can CSOs access International funding to support the implementation of child programs and the question on CSO's accountability system.

\section{Research Methodologies}

This research is qualitative descriptive research. Primary and secondary data were obtained by conducting literature review and field studies in 4 months. The implementation of the study is limited only in the issue of the effectiveness of International Funding in the implementation of the child rights in Indonesia in focused of Sumatera Utara province. Specifically, the location of research in Medan is based on two reasons. First, Medan is the capital of the Sumatera Utara province where all bureaucracy and administration are centred. Secondly, Medan is the domicile for CSO main offices that have managed international funds in the implementation of children's programs in Sumatera Utara province. Moreover, all data collection activities that literature review and interviews conducted in Medan. [13, 14] Informants are from CSO which has been working for more than 10 years in child rights in Sumatera Utara province and have visions, missions and programs related to fulfil child rights in Sumatera Utara province. In detailed, there were two leaders and two senior CSO staffs.

\section{Results and discuss}

There are three CSOs which concerns on child rights and implementing child rights programs in Sumatera Utara province. These three CSOs are involved as informants in research on the effectiveness of international funds to fulfil child rights. Firstly, Yayasan Kelompok Kerja Sosial Perkotaan (YKKSP), Education and Information Centre for Child Rights. YKKSP is a Non-profit organization which established in1987. [14]

Secondly, Centre for child study and Protection (Pusat Kajian dan Perlindungan Anak) or YPKPA. It was established on 21 October 1996. The organization was registered in the Department of Justice and Human Rights of the Republic as stated in certificate Number AHU -4047 .AH.01.02. in 2008 and Badan Kesatuan Bangsa dan Politik in Sumatera Utara Province. [15]

Thirdly, Yayasan Pusaka Indonesia (YPI). YPI is an organization concerned with child protection especially in Sumatera Utara province. YPI was established on 10 December 2000. [16] These three institutions are institutions that are concerned with the fulfilment of children's rights and are headquartered in Medan City.

Table 1. Vision and Mission of the CSOs.

\begin{tabular}{|c|c|c|c|}
\hline No & $\begin{array}{c}\text { Name of } \\
\text { CSOs }\end{array}$ & Vision & Mission \\
\hline 1 & KKSP & $\begin{array}{c}\text { to be able to take part in the } \\
\text { realization of healthy, } \\
\text { skilled, creative and } \\
\text { independent children in } \\
\text { preparing themselves for } \\
\text { maturity and spurring }\end{array}$ & $\begin{array}{c}\text { 1. Develop models of education, health } \\
\text { services and social welfare and } \\
\text { provide protection for children } \\
\text { 2. Develop a network of studies and } \\
\text { information about children in } \\
\text { improving children's rights }\end{array}$ \\
\hline
\end{tabular}




\begin{tabular}{|c|c|c|c|}
\hline No & $\begin{array}{c}\text { Name of } \\
\text { CSOs }\end{array}$ & Vision & Mission \\
\hline & & $\begin{array}{c}\text { increased public } \\
\text { participation in providing } \\
\text { protection, education and } \\
\text { health services to children. }\end{array}$ & $\begin{array}{c}\text { 3. Maintain the paths of structural } \\
\text { reform that have been taken in the } \\
\text { struggle for democracy and justice }\end{array}$ \\
\hline 2 & $\begin{array}{c}\text { PKPA } \\
\text { Foundation }\end{array}$ & $\begin{array}{c}\text { For the implementation of } \\
\text { the best interests of the child }\end{array}$ & $\begin{array}{c}\text { Advocacy for possible policy changes } \\
\text { for child well-being and protection and } \\
\text { implementation of the rights of the child. }\end{array}$ \\
\hline 3 & $\begin{array}{c}\text { Pusaka } \\
\text { Indonesia } \\
\text { Foundation }\end{array}$ & $\begin{array}{c}\text { Create an environment that } \\
\text { respects and protects the } \\
\text { Rights of the Child }\end{array}$ & $\begin{array}{c}\text { Provide services and protection of } \\
\text { children through legal aid, information } \\
\text { access, policy advocacy and community } \\
\text { empowerment to respect and protect the } \\
\text { rights of children. }\end{array}$ \\
\hline
\end{tabular}

The three CSOs are headquartered in Medan and engaged to fulfil child rights even before CRC was ratified by Indonesia through Keppres No 36 year 1990. This situation is based on the child's condition in Sumatera Utara province before 1990. There were some children labour issues namely street children, agriculture such as chocolate, rubber and palm plantation child labours. International Labour Organization (ILO) as a body which concerns with labour issue focus on special case namely Jermal issue.[17] Jermal is a large platform constructed off the ocean's coastline for fishermen, who use it to bring in the catch that they sell for their living. In particular the program of elimination of children working on the Jermal was conducted between years of 1990 to 2000 and involved two CSOs which involved in this research namely YKKSP and YPKPA.

Sumatra Utara province is known for its Palm Oil plantation industry which involves environmental and social issues. Currently, the situation and condition of child labour in Sumatera Utara province is still a concern, one of them is the condition of children in palm oil plantations. [18] It is a violation of the rules of Roundtable on Sustainable Palm Oil (RSPO). One CSO who became an informant had a program related to the issue of child labour in oil palm plantations. The program is supporting by an I-NGO in Indonesia namely ICCO. However, the program does not provide direct services for children; PKPA advocated the palm oil plantation to implement child rights issues such as should not use children as employees since it is prohibited by national and international law. The next description will discuss about the CSO programs that will be seen related to the fulfilment of 4 basic rights of children in the CRC namely the right to life, the right to grow and develop, the right to protection and the right of participation. [1,2]

\subsection{Programs on child protection}

In general, the programs of CSOs which involved in this study provided in their official website, as below:

1. KKSP Foundation

a. Giving basic rights of children and adolescents namely right to life, growth, protection and participation.

b. Providing protection for children from exploitation, other rights violations and violence.

c. Empowering communities, government and private groups that are naturally and strategically linked with children to develop greater independence, views, opinions and community participation in all aspects of life including upholding the rights of the child.

d. Developing an assessment centre and information network for child protection at local, national, regional and international levels. 
2. PKPA Foundation

a. Researches and studies about child and woman issues

b. Education and training for children and women

c. Litigation and non litigation advocacy for children and women

d. Publication and socialization of the rights of the child and woman

e. Networking for children and women

f. Child protection programs in emergency situations

3. Pusaka Indonesia Foundation, there are 6 main programs namely;

a. Access for legal services including legal assistance to children in conflict with the law.

b. Disaster respond and mitigation such as developing a safety culture through environment program.

c. Health; promoting tobacco control movement through preventing more number of early-age smokers and the suppression of the spread of infectious diseases

d. Inclusive education; to reduce and eliminate barriers to access and participation for who are discriminated against and marginalized to access their education right.

e. Entrepreneurship; to develop various business units and public fundraising in support of organizational independence that is able to contribute to community empowerment and child protection.

Programs to fulfil the child rights as committed by the three CSOs are strategies to improve the welfare of children as regulated in Law No 4 year 1979 concerning Child welfare especially child labour.[18] These CSO programs are structured as part of the CSO's role as members of in Indonesia society under article 20 Law No 35 year 2014 concerning amendment of Law No 23 year 2002 concerning Child Protection which stated "State, Government, Local Government, Community, Family, and Parents or Guardians shall be responsible and responsible for the organization of Child Protection". Another reason that should be considered is CSO programs are also a form of lack capacity of Indonesian government in handling the increase number of children's problems. [19]

Since 2016 to now, YPKA has cooperation with ICCO to advocate the rights of children who work in palm oil plantations. Based on in-depth interviews with PKPA staff, it was found that child protection programs in palm oil plantations have produced short story films to advocate palm oil plantation companies on the rights of children. They can use the movie to advocate other palm oil plantations in Indonesia to aware about child rights. There is a warning for plantation labour to should not involve their children to work in the palm oil plantation. PKPA also produced a book containing tools kits discussing the business principles and rights of children in the oil palm plantation sector. [20] This book can be guidance for the palm oil plantation to have an SOP concerning children right in palm oil plantation. This project aims to encourage the business sector to have a concern and awareness that the business has a responsibility to fulfil the rights of children especially in oil palm plantations. The PKPA staff further stated that if the oil palm company does child protection in accordance with the regulation then it is a social investment. The company not only has "prospective workers" but also "well-educated and skilled workers" in developing sustainable palm oil plantation development. It means that the palm oil companies need to invest in fulfilment of child rights.

\subsection{CSO efforts in accessing the international fund}

There are three stages when a CSO implemented its program since it is a community empowerment program. The stages are the approach with training, the attitude change and the skill improvement phase. [21] In regard to support their operational, CSO access International funding(s). Commonly, there are some strategies which can be used by CSOs 
in fundraising for examples apply the call proposal via official website of the donors. Nowadays, some CSOs worked together with their stakeholders (SHs) and communities in planning and implementing the programs including the financial aid issue.

Ben Davis mentioned in a research report concerning sustainability and diversity of fund that the financial sustainability of CSOs is a major challenge to ensure the creation of an effective Indonesian NGO sector. [22] The effectiveness of CSOs in managing international funds is part of CSO's ability to build financial sustainability and diversify. The sustainability funding is the ultimate objective to ensure the impact of the work of institutions especially CSO which concerns on child rights. [22]

International best practice shows that in order to survive, CSOs need long-term financial support from various sources. Some possible sources of funding form the basis of the CSO category, i.e. limited or unlimited funds (indication of degree of flexibility) and short-term or long-term funds (indication of sustainability). Further funds that are accessed by CSOs are: (a) grants (project funds or core funds) from international sources, such as international NGOs or international donors or domestic sources, such as government; (b) donations (endowment, one-time or regular donations, and fund-raising) from individuals, corporations or foundations; (c) self-fund (input from service activities and sales of products or services such as training, sales or technical assistance) from the government, the general public, domestic interest groups or international donors; and (d) in-kind (nonmoney) contributions (for example, office space or free work).[21]

Based on the results of interviews with the three CSOs regarding accessing the international funds, as below:

a. CSOs access international funds from UN agencies such as UNICEF, UNHCR and UNFPA. Governments of foreign countries such as US Aid, Aus-Aid and ACT-Japan. International agencies such as IOM and I-NGO such as Catholic Relief Service.

b. CSOs access the international funds through various strategies for examples through call for proposal, invitation from the donor agency, sending a mini proposal to the intended donor. Furthermore, in applying a proposal to international donors, the CSOs do it in joined application of two or more, a CSO coalition.

The strategy of accessing international funds which figure out by the three CSOs who became informants was a strategy which has been reviewed by Ben Davis's as stated above.[22] Currently, CSOs should develop independence in funding by fundraising by diversifying fund raising methods through Corporate Social Responsibility (CSR). In accessing the international fund, all CSOs provided proposals concerning child rights. In line with the proposal, they attached the logical frameworks of the child rights projects. Furthermore, in implementation of the project, they used their SOP and Children Protection Policy (CPP). These tools must be used to ensure that the projects were fitted with child rights.

One lesson learned from the CSOs that CSR was a new strategy in child rights issue. CSO advocates the oil palm plantation business by implementing child right programs. This program advocates the CSR of oil palm companies to develop child protection programs. The company developed child friendly community in the village of oil palm workers. The company facilitated the infrastructure for education in the area of oil palm plantations. However, CSR as a new fundraising strategy may also have a negative side. CSR can be a new excuse for the government in the implementation of its responsibilities as a state party of CRC which stated the state obligation to fulfil the rights of citizens including children. [23]

\subsection{Monitoring and evaluation of the international Fund}


All three CSOs access international funds directly to donor agencies domiciled abroad and within the country, Indonesia. Standard Operational Procedures (SOPs) covering administration and finance are the instruments that guide the control of the effectiveness of the use of international funds. The three CSOs mentioned that they always discuss with the donors about the administration and financial SOP in order to fit their SOP with the donors standards. They reviewed their SOP annually in the annual program meeting. The issue of sustainability is an important and fundamental issue. With that purpose all three CSOs perform social audits and not merely financial audit but also cover program audit. Program and financial audits are conducted internally and externally by teams that have been contracted by CSOs. [24] The three CSOs explained in the in-depth interview that evaluation and monitoring were conducted regularly. External audits are conducted at least once a year involving teams from outside CSOs. Audit results are further reported to donor agencies and / or the general public. After they conducted the monitoring and evaluation, they will report it to the donors periodically while for the board committees they report it annually.

\section{Conclusions}

CSO as a community group with a goal to build a community has an important role as an agent that fulfils the rights of children in Indonesia. The study shows that three CSOs headquartered in Medan, Sumatera Utara province have gained access to international funds from UN agencies, specialized bodies of the UN, foreign governments, I-NGOs and even multi-national corporations in the form of CSR. The study also shown that the international funds were effective managed by all three CSOs by using logical frame work of projects, children protection policy (CPP) and SOP in implementation the child rights program which collaboration between the CSOs and the donors. Furthermore, the organizations achieved its vision and mission as stated in their established certificate through achieving the project outputs as stated in the MoU between the CSOs and donors. Last but not least, CSO need to continue and harmonized their child program with the current condition of both environmental and social issues related to society in fulfilment the children's rights in specific child labour issue in the oil palm plantation sector.

\section{Acknowledgements}

We would like to thank the Research and Service Institute of Universitas Sumatera Utara who supported the authors to implement research program through TALENTA research scheme of Fiscal Year 2018 based on the Rector Letter Number: 433 / UN5.1.R / SK / PPM / 2018.

\section{References}

1. Convention on the Rights of the Child

2. Mohammad Farid, Kewajiban Negara dan Upaya Implementasi Konvensi Hak Anak, (to be published)

3. Mervat Rishmawi, Article 4, the Nature of States Parties' Obligation, Martinus Niijhoff Publisher, Leiden-Boston, 36 (2006) 
4. Direktorat Sosial Budaya Dan Organisasi Internasional Negara Berkembang Direktorat Jenderal Multilateral Kementerian Luar Negeri, Direktori Organisasi Internasional Non-Pemerintah (I-NGO) di Indonesia, 1-20 (2011)

5. YP2SU, Menilik Efektifitas Peran Lembaga Donor dalam Pembangunan Manusia (2017)

6. Ishartono \& Santoso T. Raharjo, Sustainable Development Goals (SDGs) dan Pengentasan Kemiskinan, SWJ, 6 (2), 154-272 (2016)

7. W. Fengler, A. Ihsan, Hope High for Acehnese to Emerge from Poverty, (The Jakarta Post, Indonesia, 2006)

8. R.A. Felayanti, Efektivitas Bantuan Luar Negeri di Aceh selama 2004 - 2010, setelah Tsunami Samudra Hindia tahun 2004, JHI, Tahun IX No.1, 31-48 (2016)

9. B. Philips, An Assessment of the Impact of the $26^{\text {th }}$ Dec 2004 Earthquake and Tsunami on Aquaculture in the province of Aceh and North Sumatera, UN Food and Agriculture Organization, Indonesia (2005)

10. M.P. Karns, K.A. Mingst, K.W. Stiles, International Organization; The Politics \& Processes of Global Governance, 241 ( 2015)

11. R.N.N. Sirait, CSO Networking; A Strategy To Achieve Asean Vision, (to be published)

12. B. Sunggono, Metode Penelitian Hukum, (PT.Raja Grafindo Persada, 103-104, 1998)

13. Dragan Milovanovic, A Primer in the Sociology of Law, (Harrow and Heston Publishers, $2^{\text {nd }}$ Edition, 1-21, 1994)

14. http://www.kkspfoundation.org/page-about-us

15. http://www.pkpaindonesia.org/index.php/tentang-kami/profil-pkpa

16. http://pusakaindonesia.or.id

17. https://news.detik.com/berita/1005086/sejumlah-anak-ditemukan-masih-bekerja-dijermal-di-sumut

18. I. Sukadi, Tanggung Jawab Negara Terhadap Anak Terlantar Dalam Operasionalisasi Pemerintah Di Bidang Perlindungan Hak Anak, DJJSH, 5 (2), Desember 2013, 117-133 (2013)

19. A.S Karokaro, Kala Anak-anak jadi Buruh Harian Pemanggul Sawit, MSBL, 17 Desember (2014)

20. A. Sofian, M. Lubis, Rosmalinda, P.S. Maharani, M.W. Lubis, S. Sucihati, Sagita, Toolkits, prinsip-prinsip bisnis dan hak anak di sektor Perkebunan Kelapa Sawit, PKPA, (2017)

21. K.S. Purba, H. Gurning, Pemberdyaan, Partisipasi dan Peranan LSM dalam Pembangunan Masyarakat, (USU Press 23-35, Medan, 2011)

22. B. Davis, Keberlanjutan Finansial dan Diversifikasi Pendanaan : tantangan bagi LSM Indonesia, (NSSC Publication, Research Series \#2, Indonesia, 2015)

23. P. Patra, A. Behar, Implications of Corporate Social Responsibility on Civil Society in India, State of Civil Society reports 2015 (2015)

24. Manoj Fogla, Social Accountability Standards for Voluntary Organisations, Financial Management Service Foundation (2007) 